\title{
CORRECTION
}

\section{Correction to: High-throughput miRNA deep sequencing in response to drought stress in sugarcane}

\author{
Athiappan Selvi ${ }^{1}$ - Kaliannan Devi $^{1} \cdot$ Ramaswamy Manimekalai $^{1} \cdot$ Perumal Thirugnanasambandam Prathima ${ }^{1}$. \\ Rabisha Valiyaparambth ${ }^{1} \cdot$ Kasirajan Lakshmi ${ }^{1}$
}

Published online: 19 July 2021

(c) King Abdulaziz City for Science and Technology 2021

\section{Correction to: 3 Biotech (2021) 11:312 \\ https://doi.org/10.1007/s13205-021-02857-x}

The authors have inadvertently duplicated Fig. 8 as Fig. 9. Correction to Fig. 9 is given below. The authors regret any inconvenience caused as a result of this error.

The original article can be found online at https://doi.org/10.1007/ s13205-021-02857-x.

Athiappan Selvi

A.Selvi@icar.gov.in; selviathiappan@yahoo.co.in

Kaliannan Devi

20biot03@selvamtech.edu.in

Ramaswamy Manimekalai

R.Manimekalai@icar.gov.in

Perumal Thirugnanasambandam Prathima

Prathima.Pt@icar.gov.in

Rabisha Valiyaparambth

VP.Rabisha@icar.gov.in

Kasirajan Lakshmi

K.Lakshmi@icar.gov.in

1 Biotechnology Section, Division of Crop Improvement,

ICAR-Sugarcane Breeding Institute, Coimbatore,

Tamil Nadu 641 007, India 


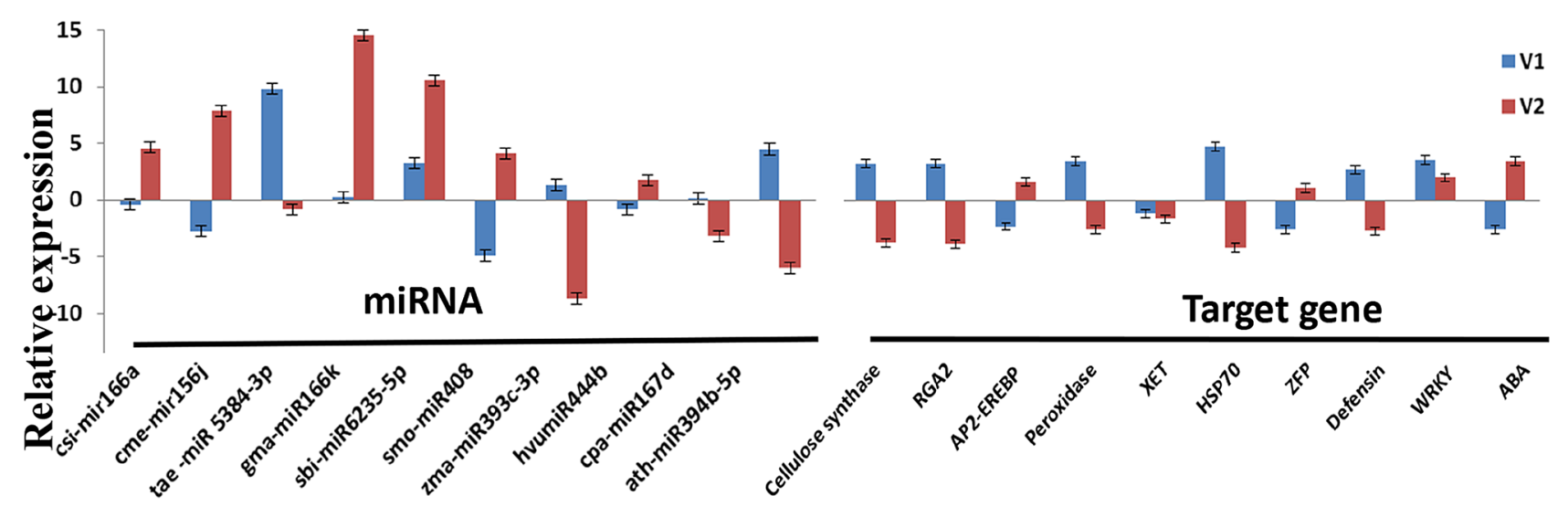

Fig. 9 Expression profiling of miRNAs and predicted target genes of drought susceptible Co 8021 (V1) and drought tolerant Co 06022 (V2) sugarcane cultivars subjected to 10 days drought stress. The target genes are cellulose synthase, $R G A 2$-Disease resistance protein RGA2, AP2-EREBP-AP2-EREBP transcription factor, peroxidase,
XET-Xyloglucan endotransglucosylase hydrolase, HSP 70-heat shock protein $70-\mathrm{kDa}, Z F P$-zinc finger domain superfamily protein, defensin, WRKY-WRKY transcription factor and $A B A$-abscisic acid. In qRT-PCR each bar represents the average of three replicates and error bars indicate SE 